\title{
Hydrodynamic Characterisation of Channel with Submerged Vegetation
}

\author{
Pencirian Hidrodinamik bagi Saluran Bertumbuhan Tenggelam
}

Siti Shara Mohd Nazri* \& Suraya Sharil

\section{ABSTRACT}

This study was conducted to investigate the hydrodynamic characterisation of channel with submerged vegetation. Aquatic plant provides a variety of ecosystem services and plays an important role in the hydrodynamic behavior, the ecological balance and the characteristics of the river. It has an effect on flow resistance and gives great impact on the water level. Laboratory experiment was conducted to investigate the effect of plant densities to flow profile using wood dowel to represent the real plant which was carried out in a hydraulic flume. Solid volume fraction (SVF) is used as vegetation density in this study whereby SVF 3.14\% as high vegetation density and SVF 0.79\% as low vegetation density. Experimental studies were conducted in uniform flow condition with Reynolds number 554 for lower vegetation density and Reynolds number 375 for higher vegetation density. Results show that the longitudinal velocity magnitude decreases approximately $30 \%$ with vegetation density increases from SVF $0.79 \%$ to SVF 3.14\%. Average velocity, u for this experiment is equal to 4.44 $\mathrm{cm} / \mathrm{s}$ for lower vegetation density and $3.00 \mathrm{~cm} / \mathrm{s}$ for higher vegetation resulting calculated Manning's roughness equal to 0.0937 for higher vegetation density and 0.0633 for lower vegetation density. Furthermore turbulent kinetic energy (TKE) and turbulent intensities are both greater in higher densities vegetated channel compared to the lower densities. Data analysis also calculated the drag coefficient, $C_{D}$ which is equal to 1.999 for higher vegetation density and 3.680 for lower vegetation density.

Keywords: Vegetation density; turbulent kinetic energy; turbulence intensities; flow resistance; drag coefficient

\section{ABSTRAK}

Kajian ini dijalankan untuk mengkaji pencirian hidrodinamik bagi saluran bertumbuhan tenggelam. Tumbuhan akuatik menyediakan pelbagai perkhidmatan ekosistem dan memainkan peranan penting dalam mempengaruhi kelakuan hidrodinamik, keseimbangan ekologi dan pencirian sungai. Tumbuhan akuatik juga memberi kesan terhadap rintangan aliran dan ketinggian paras air. Oleh itu, kajian makmal dijalankan di dalam saluran hidraulik untuk menyiasat kesan kepadatan tumbuhan terhadap profil aliran dengan menggunakan rod kayu sebagai tumbuhan. Pecahan Jumlah Pepejal (SVF) digunakan sebagai ukuran kepadatan tumbuhan, iaitu SVF 3.14\% sebagai kepadatan tumbuhan tinggi dan SVF $0.79 \%$ sebagai kepadatan tumbuhan rendah. Kajian makmal dijalankan dalam aliran seragam dengan nombor Reynolds 554 untuk tumbuhan berkepadatan rendah dan nombor Reynolds 375 untuk tumbuhan berkepadatan tinggi. Keputusan makmal menunjukkan magnitud halaju membujur menurun sebanyak lebih kurang 30\% apabila kepadatan tumbuhan meningkat daripada SVF 0.79\% kepada SVF 3.14\%. Untuk kajian ini, purata halaju aliran, u adalah $4.44 \mathrm{~cm} / \mathrm{s}$ untuk tumbuhan berkepadatan rendah dan $3.00 \mathrm{~cm} / \mathrm{s}$ untuk tumbuhan berkepadatan tinggi, seterusnya menghasilkan kiraan pekali kekasaran Manning's 0.0937 untuk tumbuhan berkepadatan tinggi dan 0.0633 untuk tumbuhan berkepadatan rendah. Seterusnya, didapati magnitud tenaga kinetik gelora (TKE) dan keamatan gelora adalah lebih tinggi dalam tumbuhan berkepadatan tinggi berbanding dengan tumbuhan berkepadatan rendah. Analisa data turut mengira pekali seret, CD bersamaan 1.999 untuk tumbuhan berkepadaran tinggi dan 3.680 untuk tumbuhan berkepadatan rendah.

Kata kunci: Kepadatan tumbuhan, tenaga kinetik gelora, keamatan gelora, rintangan aliran and pekali seret

\section{INTRODUCTION}

Vegetation is one of the important features of the river. In addition to provides habitat for aquatic life, it is also important to balance between the morphology of river channels and its hydraulic characterisation (James et al. 2001). Hydraulic characterisation will determine the shape of the river channel and habitat for the plants. Plants will affect the hydraulic environment that controls the movement of the sediments. Therefore, for sustainable river management, it requires a good understanding of this relationship, particularly the influence of vegetation on flow resistance, because it can have a major impact to the transportation process in the channel (Järvelä 2002). Resistance or drag force exerted by the plant reduced the average velocity of flow in the vegetated channel compared to areas without vegetation. Increase of drag can also lead to rise of water depth that may influence aquatic life and biological activity in the river. One of the early friction models is Manning's equation. This equation is widely 
used by engineers in determining the flow in open channel the channel, however Manning's equation is less suitable for channel with a non-uniform flow. Moreover in recent years there are experimental studies on drag force through arrays of wood dowels as the simulated plant with drag coefficient as the friction magnitude. One of the aspects studied is the relation between flows in vegetated channel with the function of Reynolds number. These types of work offer wider range of flow and vegetation characteristics that can be studied. It is known that aquatic plant reduces the average velocity, it's also may generates greater turbulent intensity and turbulent kinetic energy in a flow. Having said that, the main focus of this study is to investigate the effect of plant density on the hydrodynamic characteristics (i.e velocity, turbulence intensity, turbulent kinetic energy) and the determination of the resistance of plants using Manning coefficient, $n$, Chezy, $C$, Darcy-Weisbach, $f$ and drag coefficient $C_{D}$ in the submerged vegetated channel.

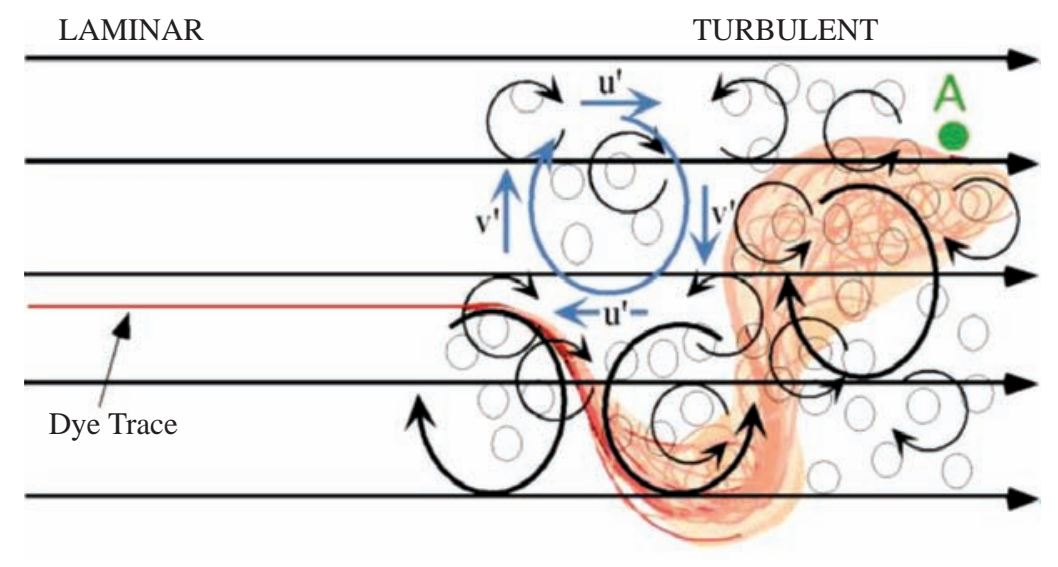

FIGURE 1. Illustration of the movement of laminar and turbulent flow at point A

Source: MIT 2005

BACKGROUND STUDY

LAMINAR AND TURBULENT FLOW

The flow is laminar or turbulent depending on the relative inertia of fluid to the viscosity of the fluid known as the Reynolds number.

Figure 1 illustrates comparison flow lines between laminar and turbulent flow. Both laminar and turbulent flow can occur in open channels depending on the Reynolds number $(R e)$. The magnitude of the Reynolds number can be calculated using equation (1). The existence of these distinct flow regimes was first investigated by Osborne Reynolds in 1883. According to Massey (1989) the flow is turbulent when the path of individual particles of fluid are sinuous, intertwining and crossing one another in a disorderly manner and at lower velocities particles of fluid may be observed to be moving entirely in a straight line and this flow is called as laminar flow.

$$
R e=\frac{\rho U L}{\mu}=\frac{U L}{v}
$$

where $\rho=$ density of the fluid, $\mu=$ dynamic viscosity, $v=$ kinematic viscosity, $U=$ average cross section velocity and $\mathrm{L}$ = hydraulics length. For this study laminar flow is considered flow with Reynolds number less than 500 and turbulent flow for Reynolds numbers above 2000 (Chadwick and Morfett 1998).
FLOW RESISTANCE

Manning roughness is commonly used for open channel design and can be calculated using equation (2). Manning's equation was named after the Irish engineer Robert Manning (Green 2005).

$$
u=\frac{1}{n} R^{\frac{2}{3}} \sqrt{S} \quad \text { (SI unit) }
$$

where $u=$ average velocity; $n=$ manning's roughness coefficient; $R$ = hydraulic radius; $S=$ bed slope. Similar to manning roughness, Chezy and Darcy Weischbach friction coefficient are very well known in river flow analysis (Stone and Shen, 2002) and can be referred as equation (3) and (4).

$$
\begin{gathered}
v=C \sqrt{R S} \\
f=\frac{8 g R S}{u^{2}}
\end{gathered}
$$

where $u=$ average velocity; $R=$ hydraulic radius; $S=$ bed slope; $C=$ Chezy's coefficient; $f=$ Darcy's friction coefficient. Besides that, flow resistance due to vegetation also can be measured using drag coefficient in equation (5)

$$
F_{D}=\frac{1}{2} \rho u^{2} C_{D} A
$$


where $F_{D}=$ drag force; $\rho=$ fluid density; $u$ = flow velocity; $A=$ cross section area; $C_{D}=$ drag coefficient. Meanwhile Manning's, Chezy's and Darcy's friction coefficient are based on uniform flow, drag coefficient is derived from the stream-wise drag force due to the form of the obstacle; i.e. vegetation (Malki 2009). Therefore $C_{D}$ is therefore is a function of the body shape and the Reynolds number (Douglas et al. 1979).

\section{TURBULENCE INTENSITY AND TURBULENT KINETIC ENERGY}

Turbulence intensity is the ratio between turbulence strength and mean velocity as shown in equation (6)

$$
\text { Turbulence intensity }=\frac{u_{r m s}}{\bar{u}}
$$

$u_{r m s}$ is turbulence strength and subscript ' $r m s$ ' stands for rootmean-square and can be describe as equation (7). A larger $u_{r m s}$ indicates a higher turbulence level.

$$
u_{r m s}=\sqrt{\overline{u^{\prime}(t)^{2}}}
$$

where $u^{\prime}=$ turbulent fluctuation.

Turbulent kinetic energy is another parameter in fluid dynamic to measure the turbulence intensity as shown in equation (8).

$$
T K E=\frac{\overline{u^{\prime 2}}+\overline{v^{\prime 2}}+\overline{w^{\prime 2}}}{2}
$$

where $u^{\prime}$ is turbulent fluctuation in $x$ direction, $v$ ' is turbulent fluctuation in $y$ direction and $w^{\prime}$ is turbulent fluctuation in $z$ direction. According to Nepf (1999) the presence of vegetation affects the turbulence due to the conversion of mean kinetic energy to turbulent kinetic energy within stems wakes augments the turbulence intensity.

\section{EXPERIMENTAL PROCEDURES}

Experiment was conducted in a flume of $9.7 \mathrm{~m}$ long, $0.6 \mathrm{~m}$ wide and $0.45 \mathrm{~m}$ deep. Wood dowel of $10 \mathrm{~mm}$ diameter was used as artificial vegetation arranged in aligned arrangement for two types of densities namely high densities and low densities vegetation. Vegetation density calculated using equation (9) also known as solid volume fraction (SVF). Therefore this experimental study takes SVF $3.14 \%$ as high vegetation density and SVF $0.79 \%$ for low vegetation density.

$$
\mathrm{SVF}=\frac{\pi d^{2}}{4 \delta_{x} \delta_{y}} \times 100 \%
$$

where $\mathrm{d}$ is the wood dowel diameter, $\delta_{x}$ is the distance between mid-centre to mid centre of the dowels in $\mathrm{x}$-direction and is the distance between mid-centre to mid centre of the dowels in y-direction as shown in Figure 2 and Figure 3.

The first stage of the experiment was to establish the uniform flow condition. Technically this can be achieved when the water surface gradient is the same with the flume base gradient. Experiments were conducted in a flow discharge of $0.00814 \mathrm{~m}^{3} / \mathrm{s}$ and flow depth of $0.37 \mathrm{~m}$ generating laminar flow (Reynolds number of 375) for higher vegetation density and transitional flow (Reynolds number of 554) for lower vegetation density. Velocity data was measured using an Acoustic Doppler Velocimeter (ADV) at the mid-section of the vegetation arrays. Velocity measurement was taken from bottom of the flume to the surface of water with the increment of $1 \mathrm{~cm}$ for each sampling point. For each sampling point two minutes of sampling times was considered. This process was repeated for the two types of vegetation densities which include high (SVF 3.14\%) and low (SVF $0.79 \%$ ) vegetation densities.
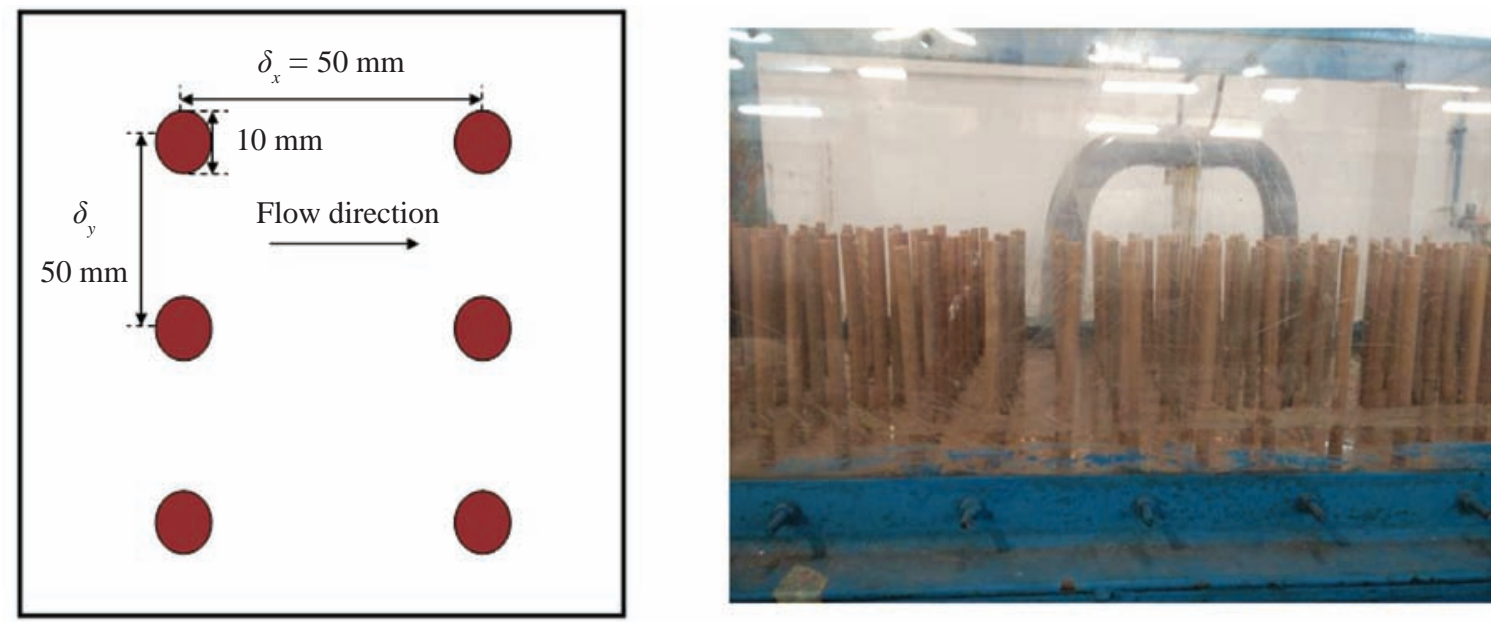

FIGURE 2. Dowels arrangement in high density vegetation 

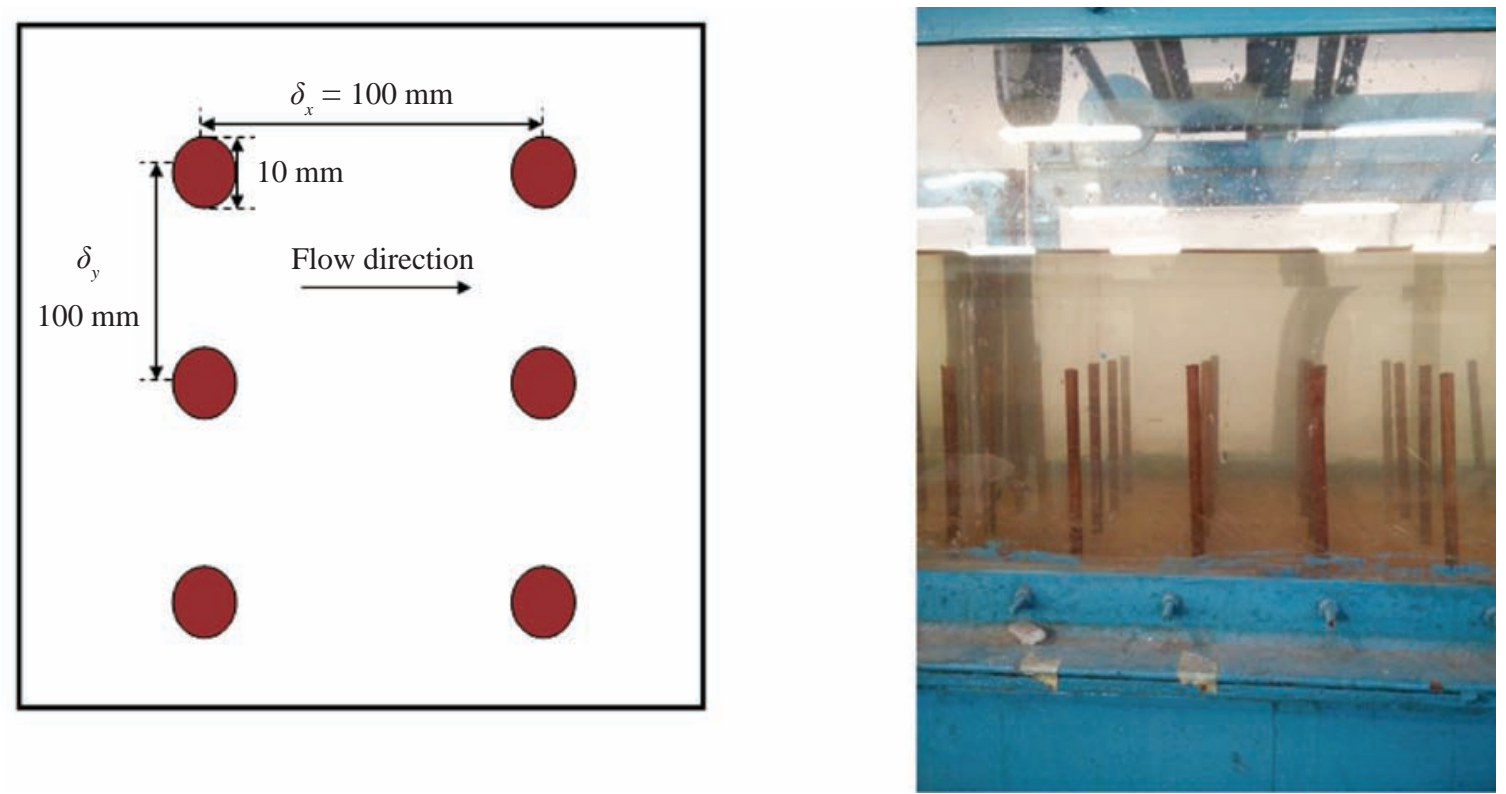

FIGURE 3. Dowels arrangement in low density vegetation

RESULT AND DISCUSSION

Table 1 tabulated results for this experimental study. The longitudinal velocity reduces by approximate of $30 \%$ between the two vegetation densities of this experiment. Observation from Figure 4 (a) shows there's only a slight or no obvious change in vertical profile of longitudinal velocity for both vegetation densities. However data shows that SVF 3.14\% has slight larger velocity gradients relative to SVF $0.79 \%$. In the case of submerged vegetation, since the experiments were conducted with the same flow discharge and water depth, higher vegetation density resulted greater different between velocities measured in vegetated area and velocities measured above the vegetation.
Experiment results in Table 1 and Figure 4 (b) and (c) show that turbulent intensities and turbulent kinetic energy increases with vegetation densities. This most probably because in higher vegetation density producing more vortex shedding from the flow passing through the dowels generating more eddies and subsequently increases the turbulence intensities and turbulent kinetic energy. This is more applicable to sparse vegetation or vegetation with SVF less than $10 \%$ because for a much denser vegetation where vegetation are located near to each other, there is more likely that wakes produces by passing flow though overlapped each other (Nepf, 2004). Therefore at certain range of vegetation density, the higher the vegetation density will lower the turbulent intensities.

TABLE 1 . The measured velocity, turbulent intensity, turbulent kinetic energy (TKE) and Reynolds number (Re) in vertical profile of the flume

\begin{tabular}{|c|c|c|c|c|c|c|c|c|}
\hline $\begin{array}{c}\text { Flow depth from bottom } \\
\text { of the flume }(\mathrm{cm})\end{array}$ & $\begin{array}{c}\mathrm{v}_{\mathrm{x}} \\
3.14 \% \\
\mathrm{~cm} / \mathrm{s}\end{array}$ & $\begin{array}{c}\mathrm{v}_{\mathrm{x}} \\
0.79 \% \\
\mathrm{~cm} / \mathrm{s}\end{array}$ & $\begin{array}{c}{\left[\mathrm{v}_{\mathrm{x}}{ }^{\prime}\right]} \\
3.14 \% \\
\mathrm{~cm} / \mathrm{s}\end{array}$ & $\begin{array}{c}{\left[\mathrm{v}_{\mathrm{x}}{ }^{\prime}\right]} \\
0.79 \% \\
\mathrm{~cm} / \mathrm{s}\end{array}$ & $\begin{array}{c}\text { TKE } \\
3.14 \% \\
\left(\mathrm{~cm}^{2} / \mathrm{s}^{2}\right)\end{array}$ & $\begin{array}{c}\text { TKE } \\
0.79 \% \\
\left(\mathrm{~cm}^{2} / \mathrm{s}^{2}\right)\end{array}$ & $\begin{array}{c}\mathrm{Re} \\
3.14 \%\end{array}$ & $\begin{array}{c}\operatorname{Re} \\
0.79 \%\end{array}$ \\
\hline 0 & 0 & 0 & 0 & 0 & 0 & 0 & 0 & 0 \\
\hline 0.5 & 2.559 & 4.006 & 1.027 & 0.919 & 1.233 & 1.055 & 319.5 & 500.1 \\
\hline 1.5 & 2.796 & 3.749 & 1.184 & 0.899 & 1.686 & 0.984 & 349.1 & 468.1 \\
\hline 2.5 & 2.938 & 3.550 & 1.228 & 0.987 & 1.710 & 1.136 & 366.8 & 443.2 \\
\hline 3.5 & 2.719 & 4.023 & 1.285 & 1.175 & 1.703 & 1.734 & 339.4 & 502.2 \\
\hline 4.5 & 2.787 & 4.013 & 1.201 & 1.032 & 1.682 & 1.125 & 348.0 & 501.0 \\
\hline 5.5 & 2.770 & 4.430 & 1.079 & 1.249 & 1.323 & 1.743 & 345.8 & 553.1 \\
\hline 7.5 & 2.894 & 4.504 & 1.060 & 1.145 & 2.461 & 1.591 & 361.3 & 562.3 \\
\hline 9.5 & 3.135 & 5.259 & 1.145 & 1.257 & 1.540 & 1.675 & 391.4 & 656.5 \\
\hline 11.5 & 3.589 & 5.341 & 1.285 & 1.131 & 1.650 & 1.532 & 448.0 & 666.8 \\
\hline 13.5 & 3.813 & 5.499 & 1.274 & 1.120 & 2.442 & 1.334 & 476.0 & 686.5 \\
\hline Purata & 3.000 & 4.437 & 1.177 & 1.091 & 1.667 & 1.391 & 374.5 & 554.0 \\
\hline
\end{tabular}




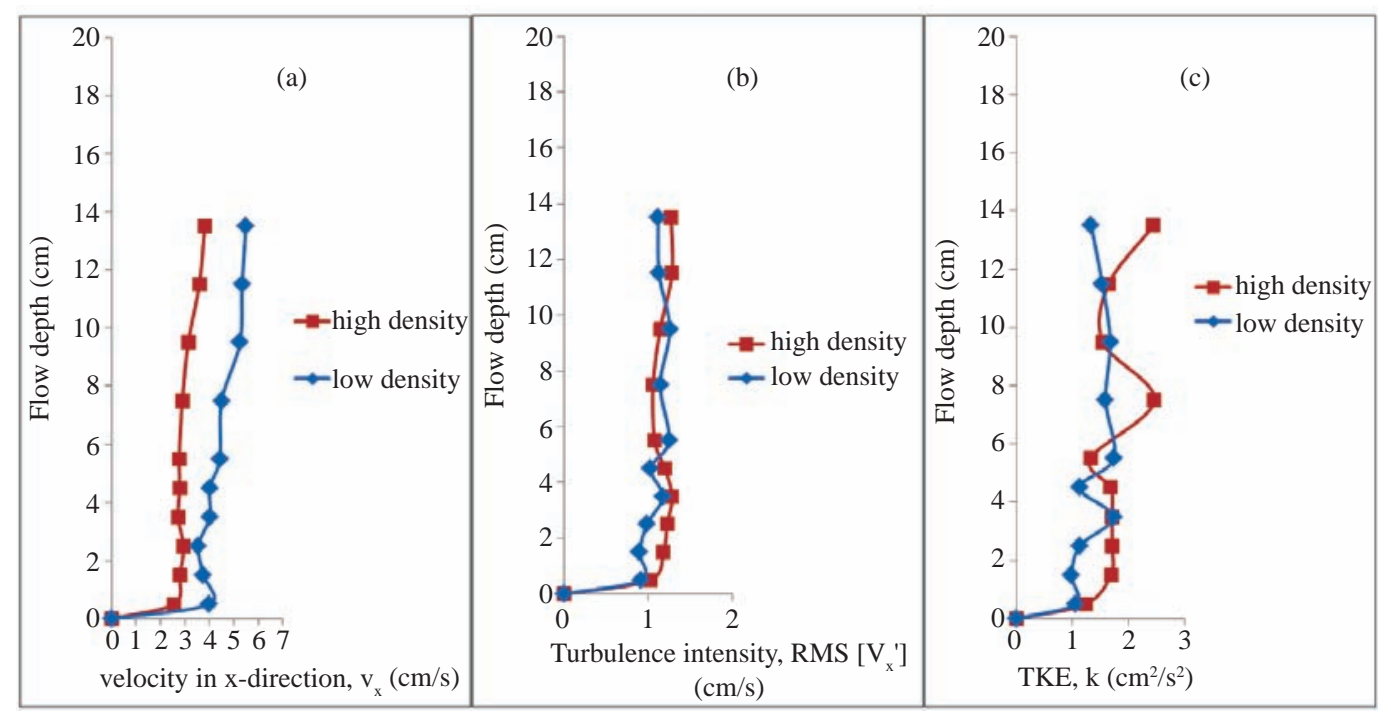

FIGURE 4. Comparison result of velocity profile, turbulence intensity and turbulent kinetic energy between high and low vegetation densities

Table 2 shows summary of friction coefficients including Manning's, Chezy and Darcy-Weisbach coefficient which present higher magnitude for denser vegetated channel. Another observation is drag coefficient decreases as the vegetation density number increases. This finding coincides with Nepf (1999) where in her research explaining that drag coefficient decreases with the vegetation density because of the wake sheltering effect. Nepf (1999) conducted experimental research with emergent and random arrangement vegetation. Considering current research using experiment with sparse vegetation, it is expected that the drag coefficient increases with vegetation. Probably because the flow condition in this study is relatively low Reynolds number, there is possibility that drag coefficient is affected from viscous and form drag forces. Therefore more data is required for further investigation.

TABLE 2. Summary of calculated friction coefficient including Manning’s, Chezy, Darcy-Weisbach and drag coefficient

\begin{tabular}{lcc}
\hline & Higher density (SVF 3.14\%) & Lower density (SVF 0.79\%) \\
\hline Average velocity, $u(\mathrm{~m} / \mathrm{s})$ & 0.030 & 0.044 \\
Manning coefficient, $n$ & 0.094 & 0.063 \\
Chezy, $C$ & 0.424 & 0.628 \\
Darcy-Weisbach, $f_{D}$ & 1.299 & 0.594 \\
Reynolds number, $R e$ & 375 & 554 \\
Drag coefficient, $C_{D}$ & 1.999 & 3.680 \\
\hline
\end{tabular}

\section{CONCLUSION}

Within the range of data given in this paper, it is able to shows the different hydrodynamic characteristic for channel with submerged vegetation with two set of vegetation densities. Selected hydrodynamic parameters were chosen including, longitudinal velocity, turbulent intensity and turbulent kinetic energy. Furthermore several friction coefficient was also calculated, such as drag, Manning's; Chezy and Darcy friction coefficient. Experiment results proven that, magnitude of mean velocity, turbulence intensity and TKE reduced in vegetation with $3.14 \%$ density relative to vegetation density of $0.79 \%$. This research also shows that all drag coefficient display larger magnitude for lower vegetation due sheltering effect but more investigation is required.

\section{REFERENCES}

Chadwick, A. \& Morfett, J. 1998. Hydraulics in Civil and Environmental Engineering. E \& FN Spon.

Douglas, J.F., Gasiorek, J.M. \& Swaffield, J.A. 1979. Fluid Mechanics. Longman, UK.

Green, J. C. 2005. Modelling flow resistance in vegetated streams: Review and development of new theory. Hydrological Processes 19(6): 1245. 
Jarvela, J. 2002. Flow resistance of flexible and stiff vegetation: A flume study with natural plants. Journal of Hydrology 269(1-2): 44.

James, C.S., Birkhead, A.L., Jordanova, A.A., Kotschy, K.A., Nicolson, C.R. \& Makoa, M.J. 2001. Interaction of Reeds, Hydraulics and River Morphology, Report 856/1/01, Water Research Commission, South Africa.

Malki, R. 2009. The Influence of Saltmarsh Vegetation Canopies on Hydrodynamics in the Iintertidal Zone. $\mathrm{PhD}$ Thesis, Cardiff University.

Massey, B. \& Smith, J. W. 1998. Mechanics of Fluids. Stanley Thornes Ltd.

MIT. 2005. Lecture notes: Basic Turbulence

Nepf, H. M. 1999. Drag, turbulence and diffusion in flow through emergent vegetation. Water Resources Research 35(2): 479-489.
Nepf, H. M. 2004. Vegetated flow dynamics. In Ecogeomorphology of Tidal Marshes, edited by S. Fagherazzi, M. Marani, and L. Blum, 137-164. [eds]. Coastal Estuar. Monogr. Ser. 59: doi: 10.1029/59CE09. Stone, B.M. \& Shen, H.T. 2002. "Hydraulic resistance of flow in channels with cylindrical roughness. Journal of Hydraulic Engineering 128(5): 500-506.

Siti Shara Mohd Nazri* \& Suraya Sharil Department of Civil and Structural Engineering Universiti Kebangsaan Malaysia, Malaysia 43600 UKM Bangi, Selangor, Malaysia *E-mail address: scha_ara92@yahoo.com 